\title{
ENVIRONMENTAL FEDERALISM IN A GLOBAL ECONOMY
}

\author{
Daniel A. Farber*
}

Once upon a time, several kingdoms decided to end their trade wars. They created a centralized rulemaker with the authority to legislate against interference with trade. Over time, however, this power greatly expanded, partly because of creative judicial interpretations. By the end of the 1900s, the rulemaker was heavily involved in environmental regulation. Environmentalists applauded this expansion, while economists worried about excessive centralization. In the meantime, the rulemaker's judicial counterpart had become unexpectedly aggressive in striking down local regulations affecting trade. This development alarmed environmentalists, while economists applauded it as a triumph for free trade. To the dismay of legal formalists, constitutional text and original intent seemed forgotten. Whether they all lived happily ever after remains to be seen.

7 HIS little fable symbolizes much of American constitutional history. It also, as it turns out, provides a rough sketch of the growth of the European Union ("E.U."). Perhaps, with the rise of the World Trade Organization ("WTO") on the one hand and the emergence of international environmental law on the other, we are also near the beginning of a similar story on the global level.'

\footnotetext{
* Henry J. Fletcher Professor of Law and Associate Dean for Research, University of Minnesota. I would like to thank Jim Chen and Dan Esty for helpful comments, and Bob Hudec for his patient tutoring on trade law.

' For a brief overview, see generally Douglas F. Brennan, Trade and Environmental Goals at a Crossroads: Challenges for Global Treaties and National Environmental Regulation, 20 Int'l Env't Rep. (BNA) 133 (Feb. 5, 1997) (discussing the current tension between free trade and environmental protection). In the end, the most significant difference may be that multilateral environmental regulation takes place internationally on the basis of ad hoc agreements, rather than through a settled institutional framework.
} 
As the fable indicates, the trade and environmental stories appeal to very different audiences, who tend to view these themes as unrelated if not antagonistic. Much of the drive toward environmental regulation is fueled by fear of a race to the bottom, in which jurisdictions are forced to compete for industry by lowering their environmental standards. Advocates of free trade consider this fear irrational. As Jagdish Bhagwati, perhaps the leading free-trade economist in the world, has said: "The fuss that is made nonetheless over the 'race to the bottom' in the political arena, as happened in the NAFTA negotiations, may then be explained either as a reaction to ill-founded fears or as a cynical ploy to advance environmental or protectionist lobbying interests." ${ }^{2}$ By contrast, environmentalists view the expanding power of free trade tribunals with alarm, as typified by the well-known "Sabotage" advertisements, produced by the Sierra Club and other environmental groups, accusing the "secretive foreign bureaucracy" created by the General Agreement on Tariffs and Trade ("GATT") of threatening critical environmental regulations. ${ }^{4}$ A global convention of rabid free-trade environmentalists could probably be held in a very small hotel.

Despite these political conflicts, free trade and environmental regimes have much in common. Environmental regulation in both the E.U. and the United States derived initially from legislative powers originally designed to eliminate trade barriers. In turn, trade tribunals tend to defer on nondiscriminatory environmental measures. Notably, the rationale for both the trade and environmental regimes is the fear that a prisoner's dilemma may lead to a race to the bottom, whether through trade restrictions or

2 Jagdish Bhagwati \& T.N. Srinivasan, Trade and the Environment: Does Environmental Diversity Detract from the Case for Fair Trade?, in 1 Free Trade and Harmonization: Prerequisites for Free Trade 159, 175 (Jagdish Bhagwati \& Robert E. Hudec eds., 1996).

${ }^{3}$ General Agreement on Tariffs and Trade, Oct. 30, 1947, 61 Stat. A-11, T.I.A.S. 1700, 55 U.N.T.S. 194 [hereinafter GATT].

${ }^{4}$ Daniel A. Farber \& Robert E. Hudec, Free Trade and the Regulatory State: A GATT's-Eye View of the Dormant Commerce Clause, 47 Vand. L. Rev. 1401, 1409-10 (1994) (quoting Sabotage, N.Y. Times, April, 1992 (advertisement)). For further discussion of the advertisement, see Eliza N. Carney \& W. John Moore, From the K Street Corridor, 24 Nat'l L.J. 1420 (June 13, 1992); Marc Levinson, Don't Look for the Union Label: It's Camouflaged, Newsweek, May 18, 1992, at 54. 
environmental laxity. ${ }^{5}$ It turns out that both kinds of races can occur only under particular-and similar-circumstances. Thus, the appropriate conditions for multilateral trade regimes often coincide with those for multilateral environmental regimes.

Today, both the economy and ecosystem increasingly must be seen as global. Devoting equal attention to both, the 1992 Rio Declaration on Environment and Development ${ }^{6}$ (the "Declaration") calls for sustainable development on a global level.' Principle 12 of the Declaration endorses an open international economic system. ${ }^{8}$ Principle 7 requires all states to "cooperate in a spirit of global partnership" to preserve the ecosystem. 'Though these two principles may sometimes appear to be in conflict, ultimately they may be mutually reinforcing. It is quite possible to favor either free trade or environmental protection as purely unilateral local policies. Anyone who favors multilateral action on either one, however, should probably favor multilateral action on the other as well. If history is any guide, the two are likely to go hand in hand. ${ }^{10}$

This Article explores the parallel evolution of environmental federalism in the United States, the E.U., and international law. The first half of the Article explores the limits placed on local regulatory powers by free-trade rules. All three legal systems are struggling to define an appropriate judicial role in reviewing local environmental regulations. The three systems have also seen a blossoming of centralized regulation in the last few decades. ${ }^{11}$ That latter development is the subject of the second half

\footnotetext{
s See Daniel C. Esty, Revitalizing Environmental Federalism, 95 Mich. L. Rev. 570, 64446 (1996) (arguing that trade law and environmental law both prevent destructive conduct by individual localities).

${ }^{6}$ Report of the United Nations Conference on Environment and Development, Rio de Janiero, June 3-14 1992, at 2, U.N. Doc. A/CONF.151/26/Rev. 1 (Vol. I) (1993).

' Id. at 3, Principles 1-2.

${ }^{8}$ Id. at 5.

Id. at 4.

"See Esty, supra note 5, at 645-46.

"This Article will use the terms multijurisdictional regulation, centralized regulation, and harmonization interchangeably. None of them should be understood to require the crudest form of centralization in which uniform requirements are imposed without regard to local conditions on all jurisdictions by a central authority. For present purposes, marketable permit schemes, decentralized goal-oriented decisionmaking, and other more flexible forms of control are considered "centralized regulations" or "harmonization" if the framework is created by the federal government, the E.U., or international treaty. On the distinction between
} 
of the Article, which analyzes multijurisdictional environmental regulation in the form of federal legislation, E.U. directives, or international treaties. Each half of the Article begins with a discussion of the economic theory concerning the need for centralized authority, whether over trade barriers or environmental issues.

\section{RESTRICTIONS ON LOCAL AUTHORITY}

One side of federalism is the constraint it places on the sovereignty of member states. Participation in a collective effort inevitably brings some loss of individual autonomy. This Part considers how collective efforts to promote trade may reduce local regulatory authority over environmental matters. ${ }^{12}$ It begins by examining the rationale for a legal regime protecting free trade, and then explores the operation of such regimes in the United States and the E.U., as well as under GATT. Similar doctrinal problems arise in all three contexts.

\section{A. The Uneasy Case for Free-Trade Rules}

There is an impressive consensus among economists that, as a general matter, free trade is a desirable policy. But simply because free trade is a good national policy does not mean that an international legal regime is the best way to effect it. Similarly, one cannot immediately leap from the premise that environmental protection is good policy to the conclusion that an international environmental regime is needed to achieve that policy. No legal solution is cost-free, so the decision to transmute a policy preference into enforceable legal rules requires some affirmative justification.

The naîve argument in favor of enforceable, international trade rules draws on the Depression-era experience with tariffs. Pursuing beggar-thy-neighbor policies, leading nations suc-

federalism and decentralization, see Edward L. Rubin \& Malcolm Feeley, Federalism: Some Notes on a National Neurosis, 41 UCLA L. Rev. 903, 910-926 (1994).

${ }_{12}$ Another aspect of federalism is the restriction it places on a jurisdiction's ability to address extraterritorial environmental problems. See generally Daniel A. Farber, Stretching the Margins: The Geographic Nexus in Environmental Law, 48 Stan. L. Rev. 1247 (1996) (discussing the geographical connection necessary to mount a cognizable claim of environmental harm both in the United States and in international legal systems). 
ceeded only in mutually impoverishing each other. ${ }^{13}$ The lesson is that tariffs are a prisoner's dilemma that may look profitable for any one nation but lead to collective disaster. ${ }^{14}$ Enforceable legal rules are needed to save nations from the temptation of engaging in this mutually destructive conduct.

The problem with this theory is that it is inconsistent with the basic policy argument for free trade. Bhagwati explains:

The theory of commercial policy, as it evolved from David Ricardo and John Stuart Mill through the writings of Alfred Marshall and Francis Edgeworth ... strongly implied that a nation would profit most by pursuing a free trade policy and that this was so whether its trading partners were free-traders or protectionists. Unilateral free trade emerged as the prescription from this corpus of thought. ${ }^{15}$

If this theory is right, free trade is a good idea, but there is no prisoner's dilemma and no race to the bottom. In fact, there is something like the opposite of a prisoner's dilemma: The socially optimal strategy happens to be the best strategy for each player, regardless of the actions of the others. Since every nation will independently favor free trade, legal constraints are unnecessary to ensure that they choose free trade as a policy.

This theory may seem a bit too good to be true, and of course it is. As Bhagwati explains, several critical assumptions underlie the argument for unilateral free trade. It is true that "[u]nder perfect competition a small, price-taking country will gain by eliminating tariffs. Consumers are better off because their incomes stretch further, and resources are used more efficiently because they are no longer used to produce goods that could be imported at a lower price."16 But the classical prescription may

". The story is told, with suitable disclaimers, in Jagdish Bhagwati, Protectionism 20-22 (1988). Beggar-My-Neighbor was the name of a 19th century card game somewhat like the modern children's game of "War." See Daniel Pool, What Jane Austen Ate and Charles Dickens Knew $62-63$ (1993).

${ }^{14}$ See Jenna Bednar \& William N. Eskridge, Jr., Steadying the Court's "Unsteady Path": A Theory of Judicial Enforcement of Federalism, 68 S. Cal. L. Rev. 1447, 1470, 1472 (1995).

${ }^{15}$ Bhagwati, supra note 13 , at 24 . For a similar argument that the Commerce Clause has been unnecessary to maintain free trade among the states, see Edmund W. Kitch, Regulation and the American Common Market, in Regulation, Federalism, and Interstate Commerce 9 (A. Dan Tarlock ed., 1981).

1k Rudiger Dornbusch, The Case for Trade Liberalization in Developing Countries, $6 \mathrm{~J}$. Econ. Persp. 69, 74 (1992). 
not be valid if a country controls a sufficient amount of the market to affect world prices or if there are other market failures. ${ }^{17}$

In the case of a purely domestic market failure, however, a tariff still may not offer the soundest policy. Even when a tariff or export subsidy could improve welfare because of a domestic market failure, a better domestic intervention (such as a tax or subsidy) exists. ${ }^{18}$ So a tariff is not sound policy in such circumstances unless these more efficient domestic policies are unavailable. By contrast, if international markets are imperfectly competitive, then various forms of strategic trade policy become more attractive to individual countries, not unlike the beggarthy-neighbor situation of the traditional story. ${ }^{19}$ In these situations, a genuine prisoner's dilemma may exist, providing a strong justification for multilateral action. ${ }^{20}$

Another rationale for free trade rules relies on flaws in political markets. Even if free trade is actually a dominant strategy in terms of national welfare, it is possible to resurrect the prisoner's dilemma concept in political guise. Free trade benefits the diffuse mass of consumers, but tariffs benefit concentrated groups of producers. These concentrated groups, according to public choice theory, may possess relative advantages in organizing and mobilizing resources. Hence, governments may be driven to erect trade barriers in order to placate local special interests, even though the result is to make their populations collectively worse off, leading to a kind of political race to the bottom. ${ }^{21}$ On this theory, free-trade rules would provide a

${ }^{17}$ Bhagwati, supra note 13 , at $25-26$.

18 Id. at 32; Dornbusch, supra note 16, at 80.

19 See Douglas A. Irwin, Against the Tide: An Intellectual History of Free Trade 207216 (1996).

${ }^{20}$ See Robert E. Baldwin, Are Economists' Traditional Trade Policy Views Still Valid?, $30 \mathrm{~J}$. Econ. Literature 804, 825-26 (1992). The prisoner's dilemma models also fit with the political process rationale for the dormant Commerce Clause. Under these models, local actions impose harm on outsider firms who are not represented in the local political process. In contrast, under perfect competition, marginal profits are zero. This means that the firm makes no profit on the last item it produces (which is why it doesn't make any more). Hence, a small drop in sales due to a trade barrier translates into little or no loss of profits. Thus, outside firms are indifferent at the margin to sales losses due to trade barriers.

${ }^{21}$ See Daniel A. Farber \& Philip P. Frickey, Law and Public Choice: A Critical Introduction 17, 23-24 (1991). 
constitutional regime which protects the general public against abuse from special interests. ${ }^{22}$

In short, economic theory ${ }^{23}$ suggests the race to the bottom might occur, justifying some multijurisdictional legal intervention, when:

1. Optimal fiscal instruments are not available to local governments;

2. Competition in product or capital markets is imperfect;

3. Public choice problems distort local decisions; or

4. Jurisdictions are large enough to affect global prices.

Thus, even given the general desirability of free trade as a policy, it is not a straightforward step to endorsing international trade law. Rather, the argument turns partly on the existence of various kinds of market failures which might create a temptation toward the erection of destructive trade barriers, and partly on surmises about the susceptibility of political institutions to special interests. ${ }^{24}$ As we will see, however, although the theoretical case for judicially enforceable free-trade rules is not al-

\footnotetext{
${ }^{22}$ The fallback argument for unilateral free trade is that zero tariffs are a readily enforceable, and usually optimal, regime, whereas efforts to take advantage of any of the exceptions would require the government to make fine distinctions which it might well be incapable of drawing in any reliable way. Irwin, supra note 19, at 228-29. This is a strong practical argument against tariffs and other explicit trade barriers since the default is an easily observable state (no tariffs or quotas). For similar reasons, a rule against explicit discrimination is also appealing, since it provides an easily enforceable rule that in most circumstances is likely to be reasonably close to the optimum policy anyway. But nontariff barriers, such as laws that burden trade without any explicit discrimination, are much less easy to detect, and it is much more difficult to identify a default state (the presumptively optimal level of regulation). Thus, to the extent that nonfacially discriminatory rules impede international trade, some government agency (if only a court) is likely to have to make fine distinctions of just the kind that economists have generally distrusted. To justify such a policy, one must have a theory of institutions which explains why a tribunal can determine the optimum level of regulation but an executive agency cannot set an optimal tariff.

"For an analysis of the traditional and contemporary arguments in favor of protection, see Dennis R. Appleyard \& Alfred J. Field, Jr., International Economics: Trade Theory and Policy 273-88 (2d ed. 1995).

${ }^{24}$ One might argue that free-trade rules are harmless, given the general desirability of free trade as at least a strong presumption, but a trade regime does involve a loss of independence and also creates a risk of mistaken and possibly injurious legal rulings. For instance, a regulation with a disparate impact on importers may actually be either too lax or too strict, so an overzealous trade tribunal may sometimes mistakenly push states toward underregulation. Also, diversity among states is often seen as inconvenient to multijurisdictional traders, so overzealous free-trade tribunals may push too hard for uniformity, impairing interjurisdictional regulatory competition.
} 
ways ironclad, this sort of legal regime has taken hold with apparent success in several significant settings.

\section{B. Legal Restrictions on Local Authority}

With little or no textual basis, the United States Supreme Court has erected an elaborate body of legal doctrines restricting state regulation. Viewed in isolation, the U.S. approach to internal trade barriers may seem peculiar. As it turns out, however, use of a tribunal to assess local regulations seems characteristic of free-trade agreements. Although other tribunals have had clearer textual bases to legitimize their efforts, their approach to local regulations has developed independently of the exact content of those texts.

\section{U.S. Law}

By its terms, the Commerce Clause is purely a grant of legislative power to Congress rather than a restriction on the states. ${ }^{25}$ This is in contrast to some other portions of the Constitution that explicitly limit state power. ${ }^{26}$ A reasonable interpretation therefore would be that the Clause has no direct effect on state regulatory power. Indeed, relying in part on this textual argument, some scholars have forcefully argued that the Commerce Clause places no limits on state power in the absence of congressional action. ${ }^{27}$

Despite this questionable textual basis, the Supreme Court has reviewed state laws under the Commerce Clause since the early nineteenth century. Because this judicial power exists even when Congress has failed to make use of its legislative authority under the Commerce Clause, it is said to stem from the "negative" or

\footnotetext{
${ }^{25}$ U.S. Const. art. I, $\$ 8, \mathrm{cl} .3$.

${ }^{26}$ See, e.g., U.S. Const. art. I, $\S 10$, cl. 2 (no state-levied impost or duty on exports or imports).

${ }^{27}$ See Julian N. Eule, Laying the Dormant Commerce Clause to Rest, 91 Yale L.J. 425 (1982); Lisa Heinzerling, The Commercial Constitution, 1995 Sup. Ct. Rev. 217; Martin H. Redish \& Shane V. Nugent, The Dormant Commerce Clause and the Constitutional Balance of Federalism, 1987 Duke L.J. 569. For an appraisal of the arguments against judicial enforcement of the dormant Commerce Clause, see Daniel Shaviro, An Economic and Political Look at Federalism in Taxation, 90 Mich. L. Rev. 895, 949-51 (1992).
} 
"dormant" Commerce Clause. Since it is familiar ground for many readers, a brief review of this doctrine should suffice. ${ }^{28}$

The key issue under current doctrine is whether the local law "discriminates" against interstate commerce. City of Philadelphia v. New Jersey ${ }^{29}$ illustrates the Court's approach to discriminatory statutes. In large part to conserve existing landfill space, the New Jersey legislature prohibited the importation of waste from other states for disposal in New Jersey. ${ }^{30}$ The Supreme Court found this legislation unconstitutional on its face: "[W]hatever New Jersey's ultimate purpose, it may not be accomplished by discriminating against articles of commerce coming from outside the State unless there is some reason, apart from their origin, to treat them differently."${ }^{31}$ Thus, under Philadelphia v. New Jersey, explicit discrimination against interstate commerce is generally prohibited. ${ }^{32}$ Even where the discrimination is less evident, the Court has held that strict scrutiny is the rule..$^{33}$

A string of Supreme Court opinions has recently extended Philadelphia $v$. New Jersey to strike down state laws targeting the interstate transportation of waste. ${ }^{34}$ The capstone of this se-

${ }^{28}$ For a more extensive doctrinal review, see Winkfield F. Twyman, Jr., Beyond Purpose: Addressing State Discrimination in Interstate Commerce, 46 S.C. L. Rev. 381, 382-409 (1995). For a recent review of the history of dormant Commerce Clause doctrine, see Stephen Gardbaum, New Deal Constitutionalism and the Unshackling of the States, 64 U. Chi. L. Rev. 483, 506-32 (1997).

29437 U.S. 617 (1978).

${ }^{30}$ See id. at $618-19,625$.

${ }^{31}$ Id. at 626-27. 29.

32 The Court recognized a minor exception for certain quarantine laws. See id. at 628-

${ }^{33}$ See Hunt v. Washington State Apple Adver. Comm'n, 432 U.S. 333, 348-54 (1977). By contrast, one modern Supreme Court opinion does uphold a facially discriminatory regulation. In Maine v. Taylor, 477 U.S. 131 (1986), the Court upheld a Maine statute banning the importation of bait fish. The Court concluded that Maine was entitled to guard against "imperfectly understood environmental risks, despite the possibility that they may ultimately prove to be negligible"; moreover, the Court concluded that Maine need not "sit idly by and wait until potentially irreversible environmental damage has occurred or until the scientific community agrees on what disease organisms are or are not dangerous before it acts to avoid such consequences." Id. at 148 (quoting United States v. Taylor, 585 F. Supp. 393, 397 (D. Me. 1984)).

${ }^{34}$ For an overview of earlier cases, see Oregon Waste Sys. v. Department of Envtl. Quality, 511 U.S. 93 (1994); Chemical Waste Management v. Hunt, 504 U.S. 334 (1992); Fort Gratiot Sanitary Landfill v. Michigan Dep't of Natural Resources, 504 U.S. 353 (1992). 
ries is $C \& A$ Carbone v. Town of Clarkstown. ${ }^{35}$ In Carbone, the Court struck down as facially discriminatory an ordinance requiring that all waste generated within the town be sent to a single government-financed processing facility. ${ }^{36}$ It is far from obvious that this ordinance was facially discriminatory against outof-state processors; indeed, four Justices believed that it should have been assessed under the milder balancing test for nondiscriminatory regulations. ${ }^{37}$

This milder inquiry derives from Pike v. Bruce Church..$^{38}$ Pike established a balancing test: "Where the statute regulates evenhandedly to effectuate a legitimate local public interest, and its effects on interstate commerce are only incidental, it will be upheld unless the burden imposed on such commerce is clearly excessive in relation to the putative local benefits. ${ }^{339}$ Since Pike, federal courts have applied the balancing test to a variety of situations implicating the Commerce Clause, ranging from state corporation laws to highway safety regulations. ${ }^{40}$

${ }^{35} 511$ U.S. 383 (1994). The Court divided 5-4 on whether this ordinance should be considered discriminatory against out-of-state disposal sites, or whether it should be governed by the more lenient balancing test. Compare id. at 389 (ordinance "regulates interstate commerce because the economic effects are interstate in reach"), with id. at 401-05 (O'Connor, J., concurring) (ordinance violates Commerce Clause as an "excessive burden on interstate commerce"), and id. at 410 (Souter, J., dissenting) (ordinance is not facially discriminatory). To add to the confusion, one of the four Justices advocating application of the balancing test thought the ordinance would have failed that test, while the other three found the law to be a constitutionally acceptable solution. Compare id. at 405-07 (O'Connor, J., concurring) (ordinance would have failed), with id. at 430 (Souter, J., dissenting) (ordinance would have passed).

${ }^{36}$ Id. at 383.

${ }^{37}$ See supra note 35 . For a critique of the entire line of cases, and Carbone in particular, see Heinzerling, supra note 27 . The lower courts have reached varying conclusions about the scope of Carbone. For example, see Gary D. Peake Excavating v. Town Bd., 93 F.3d 68,76 (2d Cir. 1996) (upholding law prohibiting operation of private landfills within town because law does not unduly burden commerce); SSC Corp. v. Smithtown, 66 F.3d 502, 514-18 (2d Cir. 1995) (allowing town to eliminate interstate shipments of waste by using a single provider of hauling services), cert. denied, 116 S. Ct. 911 (1996); Atlantic Coast Demolition \& Recycling v. Board of Chosen Freeholders, 48 F.3d 701, 712-13 (3d Cir. 1995) (New Jersey solid waste disposal regulatory scheme subject to Carbone even though not an absolute barrier to out-of-state waste disposal), aff'd in part and rev'd in part, 112 F.3d 652 (3d Cir. 1997); National Solid Wastes Management Ass'n v. Meyer, 63 F.3d 652, 662 (7th Cir. 1995) (unconstitutional for state to condition importation of waste on compliance with state recycling regulations), cert. denied, 116. S. Ct. 1351 (1996).

38397 U.S. 137 (1970).

${ }^{39}$ Id. at 142 (citing Huron Portland Cement Co. v. Detroit, 362 U.S. 440, 443 (1960)).

${ }^{+0}$ See, e.g., Edgar v. MITE Corp., 457 U.S. 624 (1982) (Illinois corporation laws); Raymond Motor Transp. v. Rice, 434 U.S. 429, 440-42 (1978) (highway safety regulations); Allied Artists Picture Corp. v. Rhodes, 679 F.2d 656 (6th Cir. 1982) (Ohio legislation 
In contrast to strict scrutiny, the balancing test in practice has become increasingly lax. Indeed, in practice, it seems to require only that the state present some evidence of a regulatory benefit, particularly when public health or safety is at stake." Courts have been reluctant "to second-guess the empirical judgments of lawmakers concerning the utility of legislation." when the balancing test is applied today to nondiscriminatory statutes, the statute generally survives. For example, the Supreme Court upheld a Minnesota ban on plastic milk cartons, purportedly for environmental reasons, even though the state's own supreme court had found the prohibition to be utterly irrational. ${ }^{43}$ If the balancing test continues to be applied in this fashion, U.S. law may be evolving toward a purely discrimination-based test in domestic trade cases. ${ }^{44}$

\section{The European Union}

The E.U. has its own equivalent of the dormant Commerce Clause in the form of provisions authorizing the European

regulating the marketing of films); Procter \& Gamble Co. v. City of Chicago, 509 F.2d 69 (7th $\mathrm{Cir}$.) (Chicago ordinance disallowing the sale of phosphate detergents), cert. denied, 421 U.S. 978 (1975).

¿ See Electrolert Corp. v. Barry, 737 F.2d 110, 113 (D.C. Cir. 1984); National Kerosene Heater Ass'n v. Massachusetts, 653 F. Supp. 1079, 1092 (D. Mass. 1986). See also J. Filiberto Sanitation v. New Jersey Dep't of Envtl. Protection, 857 F.2d 913, 922 (3d Cir. 1988) (noting the substantial local benefits of a rule requiring all trash in a New Jersey county to be deposited at one transfer station, even though the balancing test was satisfied on other grounds), aff'd in part and rev'd in part, 112 F.3d 652 (1997). In a characteristic example, the Second Circuit applied the balancing test to uphold a New York law requiring special signs, notices on menus, and special containers in restaurants for imitation cheese products. Grocery Mfrs. v. Gerace, 755 F.2d 993, 1003-05 (2d Cir.), cert. denied, 474 U.S. 820 (1985). In doing so, it reversed the district judge's finding of no health justification for this special interest legislation. Id. at 1003.

${ }^{42}$ Kassel v. Consolidated Freightways Corp. 450 U.S. 662, 679 (1981) (Brennan, J., concurring in the judgment) (focusing instead on discriminatory intent), quoted with approval in CTS Corp. v. Dynamics Corp., 481 U.S. 69, 92 (1987). In contrast, the majority in Kassel struck down the law because of the absence of any evidence of a significant regulatory benefit. Kassel, 450 U.S. at $678-79$.

${ }^{43}$ Minnesota v. Clover Leaf Creamery Co., 449 U.S. 456 (1981).

${ }^{4}$ This is a step already taken by the High Court of Australia. See Cole v. Whitfield (1988) 165 C.L.R. 360. United States Supreme Court Justices Antonin Scalia and Clarence Thomas have advocated this position. See, e.g., West Lynn Creamery v. Healy, 512 U.S. 186, 210 (1994) (Scalia, J., concurring). More recently, Justice Thomas (joined by Justice Scalia and Chief Justice Rehnquist) has argued that the dormant Commerce Clause should be entirely scrapped-instead courts should use the Export-Import Clause, art. I, $\$ 10, \mathrm{cl} .2$, to invalidate discriminatory state taxes. See Newfound/Owatonna, Inc. v. Town of Harrison, 117 S. Ct. 1590, 1620, 1628 (1997) (Thomas, J., dissenting). 
Court of Justice ("ECJ") to eliminate trade barriers. ${ }^{45}$ Article 30 of the Treaty Establishing the European Community ("EC Treaty") prohibits "[q]uantitative restrictions on imports and all measures having equivalent effect ...."47 This provision has been construed very broadly. The leading case defines it to encompass "[a]ll trading rules enacted by Member States which are capable of hindering, directly or indirectly, actually or potentially, intra-Community trade...." ${ }^{\prime 48}$ The ECJ has used Article 30 to strike down local restrictions on products, so that a product that can be marketed legally at home normally can be marketed today anywhere in the E.U. ${ }^{49}$

Notwithstanding Article 30, Article 36 allows trade restrictions "justified on grounds of public morality, public policy or public security; the protection of health and life of humans, animals or plants; the protection of national treasures possessing artistic, historic or archaeological value; or the protection of industrial and commercial property.", Article 36 adds, however, that such restrictions still must not "constitute a means of arbitrary discrimination or a disguised restriction on trade between Member States." ${ }^{\text {"51 }}$ In a key ruling, the ECJ expanded the list of justified government interests beyond those explicitly listed in Article 36. That case, commonly known as Cassis de Dijon, adopted a rule-of-reason approach to Article 30. ${ }^{53}$

\footnotetext{
${ }^{45}$ For background, see George A. Bermann, Roger J. Goebel, William J. Davey \& Eleanor M. Fox, Cases and Materials on European Community Law 317-95 (1993); Josephine Steiner, Textbook on EC Law 79-107 (4th ed. 1994).

${ }_{46}^{46}$ Treaty Establishing the European Community, Feb. 7, 1992, O.J. (C 224) 1 (1992), [1992] 1 C.M.L.R. 573 (1992) [hereinafter EC Treaty].

${ }^{77}$ EC Treaty art. 30.

${ }^{48}$ Case 8/74, Procureur du Roi v. Dassonville, 1974 E.C.R. 837, 852. This definition would seem to embrace virtually all commercial regulation. The ECJ has, however, excepted some nondiscriminatory restrictions on retail selling practices, even though these laws may diminish the volume of sales of imported products. Case C-145/88, Torfaen Borough Council v. B \& Q plc, 1989 E.C.R. 3851.

${ }^{49}$ See, e.g., Case 178/84, Commission v. Federal Republic of Germany, 1987 E.C.R. $1227,1268-76$ (striking down German prohibition on marketing beers containing additives); Case 407/85, 3 Glocken GmbH v. USL Centro-Sud, 1988 E.C.R. 4233, 4278-83 (striking down Italian requirements for pasta content).

${ }^{50}$ EC Treaty, supra note 47 , art. 36.

st Id.

${ }^{52}$ Case 120/78, Rewe-Zentral AG v. Bundesmonopolverwaltung für Branntwein, 1979 E.C.R. 649.

${ }^{53}$ Id. at 662 .
} 
The leading case applying the rule-of-reason approach to the environment is Commission v. Denmark,,$^{34}$ more commonly called the Danish Beer Case..$^{33}$ Denmark had passed a stringent mandate for reuse of beer bottles, which also imposed severe limitations on the types of bottles that could be used. ${ }^{36}$ Compliance, to no one's surprise, was far easier for Danish than for foreign firms. " The ECJ upheld the reuse requirement. ${ }^{\text {s8 }}$ It declared that "protection of the environment is one of the Community's essential objectives" which could therefore serve to limit Article $30{ }^{\text {s9 }}$ The reuse requirement was valid because the restrictions it placed on foreign goods "cannot be regarded as disproportionate," given the environmental aims of the legislation, despite the heavy impact on foreign beers. ${ }^{60}$ The bottle specifications, however, were struck down because they added relatively little environmental protection to what the reuse rule already provided, and hence were disproportionate in their effect on trade. ${ }^{61}$

The ECJ seems uncertain regarding the role of discrimination in its Article 30 analysis. In a more recent environmental decision, the Walloon Waste Disposal Case ${ }^{62}$ the ECJ upheld local restrictions on the importation of nonhazardous waste that were strikingly like the state ban struck down in Philadelphia. ${ }^{63}$ This holding might seem to indicate that the discriminatory nature of a local law is less significant in E.U. law than under the U.S.

\footnotetext{
st Case 302/86, 1988 E.C.R. 4607.

${ }^{s s}$ For good overviews of this area of E.U. law, see Andreas R. Ziegler, Trade and Environmental Law in the European Community 13-126 (1996); Richard B. Stewart, Environmental Law in the United States and the European Community: Spillovers, Cooperation, Rivalry, Institutions, 1992 U. Chi. Legal F. 41, 51-61.

.6ase 302/86, 1988 E.C.R. at 4608.

${ }^{57}$ See id. at 4609.

${ }^{58}$ Id. at 4630.

${ }^{59}$ Id. (quoting Case 240/83, Procureur de la République v. Association de défense des brûleurs d'huiles usagées, 1985 E.C.R. 531, 549).

so Id.

${ }^{61}$ Id.

${ }^{62}$ Case C-2/90, Commission v. Kingdom of Belgium, 1992 E.C.R. I-4431.

${ }^{63}$ Compare id. at I-4433 (operators of installations for the destruction, neutralization, and disposal of toxic waste "shall be prohibited from permitting or tolerating the tipping or dumping of waste from a foreign state in the installations operated by them") (citing the Decree of Waloon Regional Executive of March 17, 1983), with Philadelphia, 437 U.S. at 618 ("No person shall bring into this state any solid or liquid waste which originated or was collected outside the territorial limits of the state.") (citing 1973 N.J. Laws Ch. 363).
} 
dormant Commerce Clause. The ECJ, however, managed to classify this facial ban on imports as nondiscriminatory:

Imperative requirements [such as the environment] can indeed be taken into account only in the case of measures which apply without distinction to both domestic and imported products. However, in assessing whether or not the barrier in question is discriminatory, account must be taken of the particular nature of waste. The principle that environmental damage should as a matter of priority be remedied at source [sic], laid down by Article 130r (2) of the Treaty as a basis for action by the Community relating to the environment, entails that it is for each region, municipality or other local authority to take appropriate steps to ensure that its own waste is collected, treated and disposed of; it must accordingly be disposed of as close as possible to the place where it is produced, in order to limit as far as possible the transport of waste. ${ }^{64}$

The implication seems to be that a finding of discrimination would have been fatal or at least severely damaging. The ECJ's benign attitude toward local regulation of waste disposal is a sharp contrast to the Supreme Court's in Carbone; the two tribunals seem to have rather different notions of "discrimination."

More recently, the ECJ has indicated that rules regarding product characteristics, labeling, and packaging are prohibited, even if facially nondiscriminatory, unless "justified by a publicinterest objective taking precedence over the free movement of goods," but other restrictions on business operations are permissible "so long as they affect in the same manner, in law and in fact, the marketing of domestic products and of those from other Member States." ${ }^{365}$ The upshot seems to be that laws characterized as discriminatory are under a special disability, while nondiscriminatory laws are generally permissible, with product specifications falling in a special category subject to the rule of reason. None of this development seems to have been dictated by the texts of Articles 30 and 36, which have served more as a source of legitimacy and general inspiration than of specific legal rules.

s Id. at I-4480 (citations omitted). "Imperative requirement" seems to mean something like "compelling interest" in U.S. constitutional law.

${ }^{65}$ Cases C-267/91 \& C-268/91, Criminal Proceeding Against Keck \& Mithouard, 1993 E.C.R. I-6097, I-6098. 


\section{The International Arena}

Perhaps the most mature body of international law in existence today springs from the GATT. ${ }^{66}$ The GATT itself is a formal international agreement containing explicit prohibitions of certain kinds of protectionist trade barriers. It begins with "tariff bindings" setting maximum tariffs on an item by item basis. ${ }^{67}$ Such a prohibition on tariffs would, however, be bootless without some restriction on nontariff barriers, as the Supreme Court seems to have realized intuitively in the Commerce Clause context. Consequently, GATT also prohibits most other forms of trade barriers. GATT's prohibitions in turn are qualified by Article XX, which authorizes trade barriers dictated by other widely-accepted government regulatory objectives such as health, safety, or law enforcement. ${ }^{68}$ GATT has an elaborate adjudication and enforcement mechanism, recently strengthened by the formation of the WTO to the point where it bears some resemblance to domestic legal regimes. ${ }^{69}$

Under GATT, if a regulatory measure explicitly distinguishes between foreign and domestic goods, the first question is whether the different treatment is "less favorable" to the foreign products. If so, the measure is a prima facie violation of the national treatment requirement of Article III, Section 4, which provides:

The products of the territory of any contracting party imported into the territory of any other contracting party shall be accorded treatment no less favourable than that accorded to like products of national origin in respect of all laws, regulations

\footnotetext{
${ }^{\text {os }}$ Certainly, the legal mechanisms controlling trade barriers are far better developed today than the system (if it can be called that) for multijurisdictional environmental regulation.

${ }^{67}$ GATT, Feb. 7, 1992, O.J. (C 224) 1 (1992), 61 Stat. A91-1362, 56 U.N.T.S. 3 - 61 U.N.T.S. 208 (entered into force on November 1, 1993).

$6 *$ GATT, art. XX (as amended by Final Act).

${ }^{69}$ Final Act Embodying the Results of the Uruguay Round of Multilateral Trade Negotiations, Apr. 15, 1994, Legal Instruments-Results of the Uruguay Round vol. 1 (1994), 33 I.L.M. 1125 (1994) [hereinafter Final Act]. GATT does place serious constraints on local governments (such as American states), not just on national governments. See Barry Friedman, Federalism's Future in the Global Village, 47 Vand. L. Rev. 1441, 1453-59 (1994).
} 
and requirements affecting their internal sale, offering for sale, purchase, transportation, distribution, or use. ${ }^{70}$

Any difference that could at any point result in less favorable treatment is enough to establish a violation of Article III. ${ }^{71}$

GATT's text is awkwardly designed for assessing facially neutral regulations: Once the very low threshold of commercial disadvantage is crossed, Article III is triggered, and only the arduous Article XX defenses are available. This heavy burden may be appropriate for cases of explicit discrimination but seems too harsh for regulations that simply burden trade. Merely because a nondiscriminatory regulation sometimes results in less favorable treatment for a foreign seller, it does not necessarily deserve the same strict scrutiny as a blatantly discriminatory trade barrier. Yet, a blanket exemption for facially nondiscriminatory regulations would create a giant loophole. GATT is still searching for a doctrinal formulation that avoids this dilemma. ${ }^{72}$

Some GATT tribunals have creatively interpreted Article III, so that facially neutral regulations need not face the rigorous standards of Article XX. This approach holds that two products are not "like" (and hence, not subject to Article III's ban on discrimination) if there is a legitimate regulatory difference between them. ${ }^{73}$ This doctrine is extensively discussed in the recent $C A F E^{74}$ decision. According to the $C A F E$ panel, likeness turns on whether the regulatory distinction was made "so as to afford protection to domestic production." 75 The panel defined the phrase "so as to afford protection" as involving both the intent and the effect of changing "competitive opportunities in fa-

\footnotetext{
${ }^{70}$ GATT, art. III, $\$ 4$ (as amended by Final Act).

"See United States: Section 337 of the Tariff Act of 1930, Nov. 7, 1989, GATT B.I.S.D. (36th Supp.) at 345, 387-91 (1990) (holding U.S. patent enforcement procedures less favorable, even though not all foreign defendants were disadvantaged by them and some defendants might find this disadvantage outweighed by other advantages).

72 Two more recent and specialized GATT provisions governing national laws on the environment, both of which override Articles III and XX in their respective areas, are discussed in Steve Charnovitz, The World Trade Organization and Environmental Supervision, 17 Int'l Env't Rep. (BNA) 89 (Jan. 26, 1994).

${ }^{73}$ This approach originated with United States: Measures Affecting Alcoholic and Malt Beverages, June 19, 1992, GATT B.I.S.D. (39th Supp.) at 206, 294-95 (1993) (analyzing U.S. laws pertaining to alcoholic beverages, including beer).

${ }^{74}$ GATT Dispute Settlement Panel Report on United States Taxes on Automobiles, 33 I.L.M. 1397 (1994).

${ }^{75}$ Id. at 1448.
} 
vour of domestic products. ${ }^{.76}$ Applying this two-pronged test, the panel determined that for purposes of a luxury tax, cars costing more than $\$ 30,000$ were "unlike" cars costing less." Similarly, cars with high gasoline consumption were "unlike" more efficient cars, for purposes of a "gas guzzler" tax designed to reduce gasoline consumption. ${ }^{78}$

Whether the $C A F E$ analysis will hold up in future adjudication is unclear. ${ }^{79}$ Two recent decisions seem unsympathetic to the $C A F E$ approach. A recent panel decision (affirmed on another ground) opines that the "likeness" analysis implicates only objective product characteristics rather than regulatory objectives. ${ }^{80}$ In striking down a Japanese tax favoring shochu over vodka, the WTO's new Appellate Body also steered away from the CAFE analysis of "like product," calling instead for a "narrowly squeezed" definition of likeness. ${ }^{81}$ Rather than focusing on either the likeness concept of Article III or the specific defenses of Article XX, ${ }^{82}$ these recent decisions seem to shift the analysis toward reliance on general antiprotectionism language in both provisions as a source of flexibility. Both decisions, however, involved laws that clearly discriminated against foreign products, either by explicitly tying the regulation to the

${ }^{76}$ Id.

${ }^{n}$ Id. at 1449.

${ }^{78}$ Id. at 1452.

${ }^{79}$ For an assessment by the former director of the Legal Affairs Division of the GATT Secretariat strongly favoring this analysis, see Frieder Roessler, Diverging Domestic Policies and Multilateral Trade Integration, in 2 Fair Trade and Harmonization: Prerequisites for Free Trade? 21, 28-30 (Jagdish Bhagwati \& Robert E. Hudec eds., 1996).

${ }^{\infty}$ World Trade Organization: Report of the Panel, United States-Standards for Reformulated and Conventional Gasoline, 35 I.L.M. 274, 294, affirmed on other grounds, 35 I.L.M. 603 (1996).

${ }^{81}$ Report of the World Trade Organization Appellate Body, Japan-Taxes on Alcoholic Beverages, Oct. 4, 1996, AB-1996-2, at 30. For a discussion of the approach taken in the panel decision in the Japanese tax case and in the Appellate Body's reformulated gasoline decision, see Steve Charnovitz, New WTO Adjudication and Its Implications for the Environment, 19 Int'l Env't Rep. (BNA) 851 (Sept. 18, 1996).

${ }^{82}$ Article III, $\$ 1$ states that taxes and regulations "should not be applied to imported or domestic products so as to afford protection to domestic production." GATT art. III, $\$ 1$ (as amended in 1948). The "chapeau" to Article XX states that taxes and regulations must not be applied "in a manner which would constitute a means of arbitrary or unjustifiable discrimination between countries where the same conditions prevail" or be "a disguised restriction on international trade." GATT art. XX (as amended by Final Act). Both the Japanese tax case and the Appellate Body's reformulated gasoline decision call for a totality of the circumstances analysis in applying such language. 
point of origin or by giving favored treatment to a distinctive local product. The implications regarding less discriminatory regulations remain unclear. Developing a workable doctrinal framework to address the issue is a major challenge facing the WTO.

As we have seen, the E.U. and U.S. legal systems have also found it difficult to settle upon a satisfactory solution to this problem. Indeed, despite their very different histories, GATT, E.U. and U.S. law on trade barriers are strikingly similar. All three originated with a simple desire to eliminate tariffs, then found adjudication of nontariff barriers to be a natural adjunct, and now struggle with similar doctrinal problems. ${ }^{83}$ And despite the questions which might be raised about their theoretical foundations, all three regimes seem to be not only alive but flourishing.

\section{MULTIJURISDICTIONAL REGULATION}

Federalism is not, of course, merely a restraint on unilateral action by member states. It is also a framework for joint action. In the environmental arena, as we will see, multilateral regulation has been blossoming in the United States, the E.U., and internationally.

As with trade law, the theoretical justification for this development is not straightforward. If various localities were hermetically sealed from each other, multijurisdictional regulation would make very little sense. The argument for multijurisdictional regulation stems from the existence (or at least the perception) of harmful impacts among localities. Partially because of the success of the free-trade regimes discussed in Part I, one source of concern has been economic pressures caused by efforts to avoid burdensome environmental regulations. We begin with the theoretical literature about these spillovers. As we will see, the possibility of economic spillovers has been one basis for the growth in centralized environmental regulation.

${ }^{83}$ For further thoughts on the doctrinal issue, see Farber \& Hudec, supra note 4, at 1431- 


\section{A. Economic Theory and the Race to the Bottom}

Why should environmental regulation cut across jurisdictional lines? Why not allow each jurisdiction to pursue independently its own preferred environmental policies?

The answers involve two types of spillovers. First, environmental problems themselves may cross jurisdictional lines. Chloroflourocarbons ("CFCs") emitted in India can injure the ozone layer around the earth; sewage discharged in Switzerland can affect the water quality in Holland; smokestacks in Ohio can cause acid rain in New England. As Richard Revesz has pointed out, the economic argument for a coordinated solution in this situation is undeniable. ${ }^{84}$ Such a solution might take the form of an agreement between the affected jurisdictions to coordinate their policies, or the form of centralized regulation by some higher governmental authority.

The second type of spillover is economic rather than environmental. In a world of capital mobility, regulatory efforts may be stymied by capital flight. ${ }^{85}$ In order to attract and retain industry, a jurisdiction may lower its environmental standards, only to spark similar responses from other jurisdictions. The result is a race to the bottom, in which jurisdictions compete by progressively lowering their environmental standards. ${ }^{86}$ Only the intervention of a centralized authority can halt this destruc-

${ }^{84}$ See Richard L. Revesz, Federalism and Interstate Environmental Externalities, 144 U. Pa. L. Rev. 2341 (1996). As Revesz demonstrates, the current U.S. mechanisms used to address these environmental externalities could use improvement.

${ }^{8 s}$ The empirical evidence, however, does not suggest that environmental regulations play a major role in plant investment decisions, so "competitiveness" concerns may be misplaced. See Kirsten H. Engel, State Environmental Standard-Setting: Is There a "Race" and Is It "To the Bottom"?, 48 Hastings L.J. 271, 321-37 (1997); Arik Levinson, Environmental Regulations and Industry Location: International and Domestic Evidence, in 1 Bhagwati \& Hudec, supra note 2, at 410, 433-35, 450-53. But cf. J. Vernon Henderson, Effects of Air Quality Regulation, 86 Am. Econ. Rev. 789, 800-05 (1996) (suggesting that "heavy polluters" may move because of nonattainment regulations under the Clean Air Act); Richard B. Stewart, Environmental Regulation and International Competitiveness, 102 Yale L.J. 2039, 2050, 2076 (1993) (arguing that competitiveness effects are modest but significant).

${ }^{86}$ For discussions of the race to the bottom, see Richard L. Revesz, Rehabilitating Interstate Competition: Rethinking the "Race-to-the-Bottom" Rationale for Federal Environmental Regulation, 67 N.Y.U. L. Rev. 1210 (1992); David L. Shapiro, Federalism: A Dialogue 42-43, 81-82 (1995). In the trade context, see Robert E. Hudec, Differences in National Environmental Standards: The Level-Playing-Field Dimension, 5 Minn. J. Global Trade 1 (1996). The race-to-the-bottom argument traces at least as far back as 1933 . See Engel, supra note 85, at 280 . 
tive competition between jurisdictions. ${ }^{87}$ As Revesz explains, under this model, local jurisdictions would face a prisoner's dilemma, so that federal regulation would serve "not as an intrusion on the autonomy of states, as it is often portrayed, but rather as a mechanism by which states can improve the welfare of their citizens." ${ }^{28}$ This theory is reminiscent of the naïve, beggar-thy-neighbor justification for international trade law considered above. ${ }^{89}$

At best, environmental spillovers provide only a partial justification for much existing multijurisdictional regulation. Current regulatory systems often seem poorly designed to address these spillovers even when they exist, and many centralized regulations, such as those for hazardous waste cleanup, address scenarios where interjurisdictional spillovers are hard to identify. In contrast, supporters of environmental regulation commonly assert race-to-the-bottom arguments. ${ }^{\circ}$ As Revesz explains, the theoretical basis of this argument is far from iron clad. ${ }^{91}$ Just as unilateral action can result in an optimal trade regime, interstate competition can, under many conditions, produce economically efficient environmental regulation. ${ }^{92}$

The fundamental economics of interjurisdictional competition are analyzed in a paper by Wallace Oates and Robert Schwab. ${ }^{93}$ In their simplest model, Oates and Schwab posit a world of small jurisdictions whose residents desire environmental quality but also seek to attract business in order to raise local wages. ${ }^{94}$ In the model, all the residents in each local jurisdiction have

\footnotetext{
${ }^{87}$ See Peter D. Enrich, Saving the States from Themselves: Commerce Clause Constraints on State Tax Incentives for Business, 110 Harv. L. Rev. 377 (1996) (arguing that states, by initiating Commerce Clause litigation, can curb the use of state subsidies and tax incentives in competition for new industry); Mark Taylor, Note, A Proposal to Prohibit Industrial Relocation Subsidies, 72 Tex. L. Rev. 669 (1994) (proposing federal legislation to restrict the use of industrial relocation subsidies).

8 Revesz, supra note 86 , at 1218 . As discussed below, Revesz is skeptical about the validity of this argument. See infra note 91 and accompanying text.

${ }^{89}$ See supra notes 13-14 and accompanying text.

${ }^{90}$ See Revesz, supra note 86 , at 1224-27 (discussing Congress' explicit reliance on a raceto-the-bottom rationale in the legislative history of the Clean Air Act).

91 Id. at 1233-44.

$92 \mathrm{Id}$ at 1242.

${ }_{93}$ Wallace E. Oates \& Robert M. Schwab, Economic Competition Among Jurisdictions: Efficiency Enhancing or Distortion Inducing?, 35 J. Pub. Econ. 333 (1988).

${ }^{94}$ See id. at $335-42$.
} 
identical tastes for environmental quality. ${ }^{95}$ Each jurisdiction uses two policy instruments: an environmental quality standard (calibrated for each firm in units of pollution per unit of labor) and a tax on capital. ${ }^{96}$ In equilibrium, each jurisdiction sets the capital tax at zero and chooses a level of regulation at which the marginal value of pollution control is just equal to its marginal social cost. ${ }^{97}$ In this model, there is no race to the bottom; instead, interstate competition leads to an optimal level of environmental regulation. This model certainly provides grounds for skepticism about the general danger of a race to the bottom. ${ }^{98}$

The key conclusion of the basic Oates and Schwab modelthat there is no general tendency toward a race to the bottom unless either tax or market distortions exist-seems to be fairly robust. ${ }^{99}$ But there are significant situations, some of which are noted by Oates and Schwab themselves, in which a race to the bottom is possible. ${ }^{100}$

The basic Oates and Schwab model assumes that jurisdictions can use optimal tax instruments to finance public goods, and therefore need not resort to a tax on capital. But, as they stress, if for some reason taxes on capital do exist, environmental regulation generally will not be optimal. ${ }^{101}$ Also, the basic model disregards political problems by positing that each locality has a homogeneous population whose desires are perfectly implemented by the government. In the absence of these assumptions, optimality no longer holds:

[T] here are three distinct sources of potential distortion in local decision-making. First, if the jurisdiction does not have access

\footnotetext{
${ }^{95}$ Id. at 339.

${ }^{96}$ Id. at 336.

${ }^{97}$ See id. at 342.

98 See also Revesz, supra note 86, at 1211-12, 1242-44 (arguing that competition among states for industry will not result in a race to the bottom).

${ }^{9}$ The recent economic literature is carefully reviewed in John Douglas Wilson, Capital Mobility and Environmental Standards: Is There a Theoretical Basis for a Race to the Bottom?, in 1 Bhagwati \& Hudec, supra note 2, at 393 . See also Esty, supra note 5, at $627-$ 38 (analyzing recent economic models of the race to the bottom). Commentators have noted, however, that problems may arise if multiple jurisdictions use different kinds of regulatory instruments-for example, if some use emission regulations and others use emission fees. See Susan Rose-Ackerman, Environmental Policy and Federal Structure: A Comparison of the United States and Germany, 47 Vand. L. Rev. 1587, 1592-93 (1994).

${ }^{100}$ Oates \& Schwab, supra note 93, at 350-51.

${ }^{101}$ Id. at 342-45.
} 
to efficient tax instruments-if, as in our analysis, it is constrained to tax capital-then distortions occur in both fiscal and environmental decisions. More specifically, communities, because of the fiscal effects associated with environmental decisions, will opt for a socially excessive level of pollution. Second, if public decisions deviate from the will of the electorate (as in our Niskanen model), then efficient outcoines, not surprisingly, are not to be expected. In particular, we found that (as in the tax-constrained case) revenue-maxinizing behavior will lead to excessive taxation of capital and suboptimal environinental quality in the jurisdiction. And third, conflicts of interest within a heterogeneous community can also introduce distortions into public decisions. Depending on which group gets the upper hand, such conflict can result in either the taxation or the subsidization of capital with consequent inefficiencies in decisions on environmental amenities. ${ }^{102}$

The Oates and Schwab models also assume perfect competition. As later work shows, interstate competition may not produce optimum results when labor markets deviate from the neoclassical model (leading to involuntary unemployment), or investments are lumpy (which can prompt bargaining between states and firms). ${ }^{103}$ Local environmental regulations may also be nonoptimal when some jurisdictions are large enough that their regulatory decisions can affect commodity or capital prices. ${ }^{104}$ The result can be either a race to the bottom or excessive environmental regulation, depending on circumstances.

Thus, theory suggests that the race to the bottom, or other regulatory distortions, might occur when:

${ }^{102}$ Id. at 350-51. See also Wilson, supra note 99 , at 408 (noting that a capital tax distortion could result in a race to the bottom). A race to the bottom may also take place if, as suggested by survey data, government decisionmakers mistakenly believe that regulatory severity influences location decisions when actually it does not. See Engel, supra note 85, at 337-47.

${ }^{103}$ Wilson, supra note 99 , at $413-16,420-22$.

${ }^{104}$ See Ravi Kanbur, Michael Keen \& Sweder Van Wijnbergen, Industrial Competitiveness, Environmental Regulation and Direct Foreign Investment, in The Economics of Sustainable Development 289, 290, 299 (Ian Goldin \& L. Alan Winters eds., 1995). See also Bhagwati \& Srinivasan, supra note 2, in 1 Bhagwati \& Hudec, supra note 2, at 201-202 (analyzing the "large country" case); John McLaren, Size, Sunk Costs, and Judge Bowker's Objection to Free Trade, 87 Am. Econ. Rev. 400 (1997) (analyzing the "small country" case in which irreversible investments create bargaining leverage for large trading partner). 
1. Optimal fiscal instruments are not available to local governments;

2. Competition in labor, product or capital markets is imperfect;

3. Public choice problems distort local decisions; and

4. Jurisdictions are large enough to affect global prices.

Since Revesz's influential article debunking naïve theories of the race to the bottom, efforts to rehabilitate the argument often emphasize the third factor, defects in local governments. ${ }^{105}$

This analysis-and particularly the four factors listed aboveshould seem familiar. The conditions calling for a multilateral environmental regime are quite similar to those calling for a multilateral trade regime. ${ }^{106}$ In a world of perfect interjurisdictional competition, there is no need for multilateral environmental regulation except to account for physical spillover effects. Similarly, in a world of perfect interjurisdictional competition, there is also no need for legal restraints on trade barriers.

Indeed, in a perfect world, any multijurisdictional regulations that do exist must be optimal responses to some problem other than the race to the bottom, because in such a world multijurisdictional regulations would never be misused. In the absence of public choice problems, the central government would choose optimal environmental regulations with appropriate tailoring to local preferences. Even in the presence of public choice problems (i.e., wealth transfers to the median voter), the existence of optimal fiscal instruments would guarantee that any rentseeking would take the form of lump sum taxes and subsidies, rather than inefficient environmental regulations. So, in an ideal world, we would find no need for rules guaranteeing free trade, no environmental race to the bottom, and multijurisdictional environmental rules that are optimally designed.

We live, alas, in an unhappily imperfect world, in which it is quite likely that none of these ideal conditions fully prevail. This reality, however, does not, in itself, necessarily justify legal

\footnotetext{
${ }^{105}$ See William W. Buzbee, Brownfields, Environmental Federalism, and Institutional Determinism, 21 Wm. \& Mary Envtl. L. \& Pol'y Rev. 1, $45-46$ (1997); Stewart, supra note 85, at 2060; Peter P. Swire, The Race to Laxity and the Race to Undesirability: Explaining Failures in Competition Among Jurisdictions in Environmental Law, Yale L. \& Pol'y Rev./Yale J. on Reg., Joint Symposium Issue 67, 98-105 (1996).

${ }^{16}$ See supra note 23 and accompanying text.
} 
intervention. To begin with, the imperfections may not be large enough to matter in a particular case, so the basic model may still be an adequate guide to policy. ${ }^{107}$ Moreover, even if the imperfections are serious, legal intervention may not be warranted for two other reasons. First, central intervention may be futile, if jurisdictions can readily shift to other, equally undesirable policy instruments. As Revesz points out, attempting to halt an environmental race to the bottom could simply shift the distortions into the realm of taxation. ${ }^{108}$ Second, whatever flaws exist in interstate competition may be replicated at a higher level of government. If local jurisdictions provide insufficient support for free trade or environmental quality because of political defects, the same problems may simply replicate themselves in multijurisdictional regimes. What is required instead is a careful, comparative institutional analysis, to determine what flaws exist and which level of government is best able to respond.

Despite these theoretical concerns, as we will see below, the general tendency has been to strengthen multilateral regulation, just as it has been with trade law, despite similar theoretical concerns. We should be wary of criticizing this trend on the basis of theory. If we assume that political institutions perform reasonably well, this trend presumably reflects genuine needs. On the other hand, if political institutions do not perform reasonably well, then the race to the bottom is a definite possibility, so multilateral regulation may turn out to be justified on that ground.

${ }^{107}$ It is worth noting, however, that even slight imperfections may be enough to spoil the optimality of interjurisdictional competition:

More generally, to the extent that models of Tiebout-like competition are critical to arguments that interjurisdictional competition will yield optimal levels of public goods-including environmental quality, labor standards, and the like-it is important to recall Truman F. Bewley's (1981) critique of Tiebout models. As he demonstrated, the conditions under which competition among jurisdictions can be shown, in general, to yield an equilibrium that is Pareto optimal are very restrictive.

Alvin K. Klevorick, Reflections on the Race to the Bottom, in 1 Bhagwati \& Hudec, supra note 2, at 461 . Some of the restrictions on Tiebout models are discussed in David A. Starrett, Foundations of Public Economics 77-83 (1988).

${ }^{108}$ Revesz, supra note 86 , at $1246-47$. Similarly, abolishing tariffs serves little purpose if jurisdictions can merely erect nontariff trade barriers, and efforts to abolish those barriers may founder if jurisdictions can devise sufficiently subtle ways of impeding trade. 


\section{B. The Legal Regimes}

In Part I, we observed strong resemblances between the legal regimes regarding free trade in the United States, the E.U., and the international realm. In addition, the United States and the E.U. have experienced similar trends toward expansion of central legislative powers to deal with environmental issues. Multilateral environmental regulation has also increased rapidly at the international level, but from an extremely low baseline, so it is difficult to predict whether the ultimate result will be a strong system of global environmental protection. In all three legal systems, the breakdown of economic boundaries by free trade seems to have contributed to a more global outlook on environmental matters as well. ${ }^{109}$

\section{U.S. Law}

Motivated in large part by concern about state trade barriers, ${ }^{10}$ the Commerce Clause empowers Congress to "regulate Commerce with foreign Nations, and among the several States, and with the Indian Tribes."'11 Although the scope of this power was narrowly construed until the New Deal ${ }^{112}$ in the modern era it has been given a very broad interpretation. For example, in 1981, the Supreme Court upheld a federal statute that intensively regulated strip mining. ${ }^{113}$ The Court was unfazed by the argument that such land use controls have long been the province of the states. ${ }^{114}$ The test was simply whether Congress had a rational basis for determining that strip mining, as a class of activity, has a cumulative effect on interstate commerce. ${ }^{115}$ The Court observed that strip mining can cause water pollution, an

\footnotetext{
${ }^{109}$ The environmental side agreements to NAFTA provide an example. See C. Ford Runge, Freer Trade, Protected Environment 57-70 (1994).

${ }^{10}$ For a recent review of the history, see Jacques LeBoeuf, The Economics of Federalism and the Proper Scope of the Federal Commerce Power, 31 San Diego L. Rev. 555, 605-606 (1994).

"11 U.S. Const. art. I, § 8, cl. 3.

${ }^{112}$ See, e.g., Carter v. Carter Coal Co., 298 U.S. 238 (1936); Hammer v. Dagenhart, 247 U.S. 251 (1918); United States v. E.C. Knight Co., 156 U.S. 1 (1895).

${ }^{113}$ Hodel v. Virginia Surface Mining \& Reclamation Ass'n, Inc., 452 U.S. 264 (1981).

${ }^{114}$ See id. at 284-88.

115 Id. at 276-77.
} 
interstate concern. ${ }^{116}$ The Court also invoked the race to the bottom, relying on a congressional finding that nationwide standards were needed "in order to insure that competition in interstate commerce among sellers of coal produced in different States will not be used to undermine the ability of the several States to improve and maintain adequate standards on coal mining operations within their borders." 117

In a companion case, the Court rejected another attack on the same statute. ${ }^{118}$ The trial court had struck down the provisions of the statute protecting prime farm land, finding that mining disturbed less than one ten-thousandth of the nation's farm land annually and that its effect on interstate commerce was "infinitesimal." 19 The Supreme Court held, however, that the inquiry was not quantitative but merely whether some effect on commerce existed. ${ }^{120}$

Given decisions such as these, congressional regulatory power seemed well-nigh unlimited. ${ }^{121}$ Congress was not shy about exercising this power. Between 1965 and 1980, Richard Stewart reports, "Congress adopted sweeping new environmental, health, safety, and antidiscrimination regulatory statutes. There are at present over sixty major federal programs regulating business and non-profit organizations." 122 At the time, the constitutional basis for these programs seemed unquestionable.

By the late 1980s, however, some conservative theorists were beginning to lay the groundwork for a retreat from this expansive view of federal power. Raoul Berger continued his cam-

${ }^{116}$ Id. at 280.

${ }^{117}$ Id. at 281-82 (quoting 30 U.S.C. $\$ 1201$ (g) (1976 \& Supp. III 1979)).

$" 18$ Hodel v. Indiana, 452 U.S. 314 (1981).

119 Id. at 322.

${ }^{120}$ See id. at 324-25.

${ }^{121}$ The Court has provided for a limited exception relating to direct federal regulation of state governments, such as mandates that states regulate in certain areas or that state entities comply with federal regulations. See Printz v. United States, 117 S. Ct. 2365 (1997) (holding that the federal government may not force local sheriffs to assist in enforcing gun control law); New York v. United States, 505 U.S. 144 (1992) (holding that the federal government may not compel a state to enforce a federal environmental statute); National League of Cities v. Usery, 426 U.S. 833 (1976) (holding federal minimum wage law unconstitutional as applied to state governments), overruled by Garcia v. San Antonio Metro. Transit Auth., 469 U.S. 528 (1985). This aspect of federalism is outside of the scope of this Article.

${ }^{122}$ Richard B. Stewart, Madison's Nightmare, 57 U. Chi. L. Rev. 335, 339 (1990). 
paign on behalf of unadulterated originalism with a book on federalism. ${ }^{123} \mathrm{He}$ argued that the Commerce Clause extends only to trade across state lines,${ }^{124}$ and that the Supreme Court's Commerce Clause doctrines are ripe for reevaluation. ${ }^{125}$ Richard Epstein argued the doctrinal point in more detail. Specifically, he endorsed the view that "the Ford Motor Company did not manufacture goods in interstate commerce, but the Northern Pacific Railroad shipped them in interstate commerce."126 Epstein concluded in no uncertain terms: "The affirmative scope of the commerce power should be limited to those matters that today are governed by the dormant commerce clause: interstate transportation, navigation and sales, and the activities closely incident to them. All else should be left to the states." ${ }^{\text {"27 }}$

This debate seemed entirely academic until the Supreme Court put its weight behind the effort to limit federal legislative power in United States v. Lopez. ${ }^{128}$ Chief Justice William H. Rehnquist's opinion invalidated a federal ban on possession of firearms in the vicinity of schools ${ }^{129}$ (a subject on which the need for federal regulation admittedly does seem less than obvious). At the outset, Chief Justice Rehnquist invoked Madison's characterization of federal powers as "few and defined" and state powers as "numerous and indefinite."130 Admittedly, he added, the scope of federal power had greatly increased in the postNew Deal era, partly because of the "great changes" in the economy and partly because of a desire to eliminate "artificial[" restraints on federal power. ${ }^{131}$ Chief Justice Rehnquist concluded, however, that the school gun law did not fall squarely within the post-New Deal judicial holdings, and he declined to expand the scope of the commerce power further. ${ }^{132}$

\footnotetext{
${ }^{123}$ Raoul Berger, Federalism: The Founders' Design (1987).

${ }^{124}$ See id. at 123-26.

${ }^{125}$ See id. at 177-92.

${ }^{126}$ Richard A. Epstein, The Proper Scope of the Commerce Power, 73 Va. L. Rev. 1387, 1442 (1987).

${ }^{127} \mathrm{Id}$. at 1454 .

128514 U.S. 549 (1995).

${ }^{129} \mathrm{Id}$. at 551-68.

${ }^{130} \mathrm{Id}$. at 552 (quoting The Federalist No. 45, at 292-93 (James Madison) (Clinton Rossiter ed., 1961)).

${ }^{131}$ Id. at 556.

132 Id. at $561-69$.
} 
Justice Clarence Thomas argued that the majority had not gone nearly far enough. Like Epstein and Berger, he argued that modern Commerce Clause jurisprudence is almost wholly illegitimate.$^{133}$ His analysis rested on two premises. First, commerce consists only of sales, transactions, and transportation in connection with those transactions. ${ }^{134}$ Second, most areas of life should be subject only to state regulation, "even many matters that would have substantial effects on commerce": $:^{135}$

[D]espite being well aware that agriculture, manufacturing, and other matters substantially affected commerce, the founding generation did not cede authority over all these activities to Congress. Hamilton, for instance, acknowledged that the Federal Government could not regulate agriculture and hike concerns ..... ${ }^{136}$

Epstein and Berger, who had seemed so far outside the mainstream a few years before, now had the solid support of at least one Justice.

It remains to be seen how much Lopez will actually affect the scope of federal regulatory power. Justice Anthony M. Kennedy's concurrence (joined by Justice Sandra Day O'Connor) is more tentative than the majority opinion, and repeatedly suggests that the Court's role is to protect the current balance of power between the states and the federal government, rather than to begin a rollback of federal power. ${ }^{137}$ Taking the Rehnquist and Kennedy opinions together, Lopez seems unlikely to fulfill Justice Thomas's hope for a major rollback of federal power. The scholarly response to Lopez has on the whole been negative ${ }^{138}$ and most lower courts have not seen Lopez as signaling a major shift of power back to the states. ${ }^{139}$

${ }^{133}$ Id. at 584-602 (Thomas, J., concurring).

${ }^{134}$ See id. at 585-87 (Thomas, J., concurring).

${ }^{135}$ Id. at 590 (Thomas, J., concurring).

${ }^{136}$ Id. at 591 (Thomas, J., concurring).

${ }^{137}$ See id. at 576-77 (contending that citizens need to be able to identify responsibility for government action, making use of traditional boundaries between the activities of those governments); id. at 580-81 (Kennedy, J., concurring) (arguing that gun control act infringes upon states' traditional regulation of education).

${ }^{138}$ For commentary on Lopez, see Daniel A. Farber, The Constitution's Forgotten Cover Letter: An Essay on the New Federalism and the Original Understanding, 94 Mich. L. Rev. 615, 622-26 (1995); Philip P. Frickey, The Fool on the Hill: Congressional Findings, Constitutional Adjudication, and United States v. Lopez, 46 Case W. Res. L. Rev. 695 
Congress has used the commerce power as the basis for regulating air and water pollution, hazardous waste disposal, and a host of other environmental problems. For the present, at least, the massive body of federal environmental statutes resting on the commerce power seems safe from constitutional attack. Lopez does, however, seem to leave open the possibility of attacking some peripheral federal environmental regulations, such as laws that govern noncommercial activity in a traditional area of state concern and lack any evident interstate impact. ${ }^{100}$ So far, though, it is unclear that even those peripheral attacks will be successful.

\section{European Community Law}

The modern E.U. has its origins in a 1951 agreement covering coal and steel, ${ }^{141}$ which was broadened into a general commonmarket agreement by the Treaty of Rome in 1957.142 At that point, its exclusive focus was free trade. The original expectation was that the community's legislative powers would be few and limited, much like the original intent depicted by Chief Justice Rehnquist in Lopez. As George Bermann explains, "[d]ifficult as it may now be to believe, the founders of the Community appear to have expected the Community institutions to intervene only in very specific ways in the Member State economies.",143 Except in a few purely trade-related areas, they expected strict compliance with explicit grants of power. ${ }^{144}$ Over

(1996); Herbert Hovenkamp, Judicial Restraint and Constitutional Federalism: The Supreme Court's Lopez and Seminole Tribe Deçisions, 96 Colum. L. Rev. 2213 (1996); Lawrence Lessig, Translating Federalism: United States v. Lopez, 1995 Sup. Ct. Rev. 125.

${ }^{139}$ See United States v. McMasters, 90 F.3d 1394, 1397-99 (8th Cir.), cert. denied, 117 S. Ct. 783 (1996); United States v. Genao, 79 F.3d 1333, 1336-37 (2d Cir. 1996); United States v. McAllister, 77 F.3d 387, 389-90 (11 th Cir.), cert. denied, 117 S. Ct. 262 (1996); United States v. Bishop, 66 F.3d 569, 575-85 (3d Cir.), cert. denied, 116 S. Ct. 681 (1995). See generally, Note, Andrew Weis, Commerce Clause in the Cross-Hairs: The Use of LopezBased Motions to Challenge the Constitutionality of Federal Criminal Statutes, 48 Stan. L. Rev. 1431 (1996) (examining the response of the lower courts to Lopez).

${ }^{1+4}$ See Hoffman Homes, Inc. v. EPA, 999 F.2d 256, 260-61 (7th Cir. 1993) (pre-Lopez case upholding federal regulation of isolated wetlands under the Clean Water Act).

${ }^{11}$ Treaty Establishing the European Coal and Steel Community, Apr. 18, 1951, 261 U.N.T.S. 140.

${ }_{142}$ Treaty Establishing the European Economic Community, Mar. 25, 1957, 298 U.N.T.S. 11 [hereinafter EEC Treaty].

${ }^{1+3}$ George A. Bermann, Taking Subsidiarity Seriously: Federalism in the European Community and the United States, 94 Colum. L. Rev. 331, 355 (1994).

${ }^{14}$ Id. 
time, however, central authority over environmental matters expanded, partly because of broad judicial interpretations and partly because of amendments expanding environmental authority. ${ }^{145}$ Thus, as in the United States, environmental regulation in the E.U. has increasingly come under central direction. ${ }^{146}$

The Community's legislative authority was originally based on Article 100, authorizing the issuance of "directives for the approximation of such laws, regulations or administrative provisions of the Member States as directly affect the establishment or functioning of the common market."147 These directives required unanimous agreement of the members, but Article 100a later authorized legislation by a "qualified majority" to harmonize national legislation in order to promote the internal market. ${ }^{148}$ Without the requirement of unanimous consent, for the first time one could truly speak of legislative authority as opposed to an ongoing forum for negotiating consensual agreements. As Bermann points out, the scope for harmonization was potentially quite broad. Every local regulation relating to health, education, or public safety "is transformed into a Community matter to whatever extent the federal political branches find that the cross-border mobility of goods (or, by parallel reasoning, workers, services, or capital) would be advanced by bringing the various national rules on the subject into closer alignment with each other." 149

The Single European $\mathrm{Act}^{150}$ explicitly recognized environmental protection as a community objective, adding Article 130 to pro-

${ }^{145}$ See Frederick M. Abbott, Regional Integration and the Environment: The Evolution of Legal Regimes, 68 Chi.-Kent L. Rev. 173, 181-88 (1992); Clíona J. M. Kimber, A Comparison of Environmental Federalism in the United States and the European Union, 54 Md. L. Rev. 1658, 1666-67 (1995). Some of the important community directives are discussed in Turner T. Smith, Jr. \& Roszell D. Hunter, The European Community Environmental Legal System, [1992] 22 Envtl. L. Rep. (Envtl. L. Inst.) 10,106 (Feb. 1992). On the roots of this dynamic, see Esty, supra note 5.

${ }^{146}$ For a detailed discussion, see Ziegler, supra note 55, at 131-89. These developments, combined with the Article 30 cases, see supra Section I.B.2, support the assertion that central courts are likely to be more vigorous in policing local governments than in policing their own legislative peers. See William N. Eskridge, Jr. \& John Ferejohn, The Elastic Commerce Clause: A Political Theory of American Federalism, 47 Vand. L. Rev. 1355 (1994).

${ }^{147}$ EC Treaty, supra note 47, art. 100.

ids Id. art. 100a; Stewart, supra note 55 , at 56.

${ }^{149}$ Bermann, supra note 143 , at 356-57.

${ }^{150}$ Single European Act, Feb. 17 - Feb. 28, 1986, O.J. (L 169) 1 (1987). 
vide direct authority over environmental matters. Under Article 130 s this authority was broad in scope, but Article 130s imposed a special consultation procedure and required unanimous consent. Under Article 100a, however, measures relating to the achievement of the internal market required only a qualified majority ${ }^{151}$ As a result, a dispute arose over the proper scope of Article 100a. The leading case is the so-called Titanium Dioxide decision, which upheld the use of Article 100a as the basis of controls on titanium dioxide processing wastes. ${ }^{152}$ The ECJ explained the scope of Article 100a as follows:

[P]rovisions which are made necessary by considerations relating to the environment and health may be a burden upon the undertakings to which they apply and, if there is no harmonization of national provisions on the matter, competition may be appreciably distorted. It follows that action intended to approximate national rules concerning ... production conditions in a given industrial sector is conducive to the attainment of the internal market and thus falls within the scope of Article 100a, a provision which is particularly appropriate to the attainment of the internal market. ${ }^{1.33}$

The Maastricht Treaty ${ }^{154}$ further strengthens the E.U.'s environmental authority by restricting the need for unanimous consent. ${ }^{155}$ Except for land use, water use, and energy regulations, the cooperation procedure now applies to all environmental legislation, so that only a qualified majority is required. This change is expected to eliminate most of the dispute over the scope of Ar-

${ }^{151}$ EC Treaty, supra note 47, art. 1305; see also Stewart, supra note 55, at 49 (discussing changes brought about by the Single European Act).

152 Case C-300/89, Commission v. Council, 1991 E.C.R. I-2867.

153 Id. at I-2901. A later decision, Case C-155/91, Commission v. Council, 1993 E.C.R. I939, held that Article 100 a did not apply to a general directive dealing with hazardous waste because harmonization was only an incidental purpose, so that Article 130s was the appropriate source of authority. Id. at I-968-69; see also Martin Coleman, Environmental Barriers to Trade and European Community Law, Eur. Envtl. L. Rev., Dec. 1993, at 295, 307-08 (discussing Titanium Dioxide case and Articles 100a and 130s).

1s: See ECTreaty, supra note 47.

155 This expansion of central power is somewhat balanced by an increased emphasis on the principle of subsidiarity. See Bermann, supra note 143. Also, it is important to note the existence under Articles 100a and 130 of what Clay Gillette calls "local trumps." See Clayton P. Gillette, The Exercise of Trumps by Decentralized Governments, $82 \mathrm{Va}$. L. Rev. 1347 (1997). For a discussion of these local trumps, whose scope is somewhat controversial, see Ziegler, supra note 55, at 167-68, 175-78. 
ticle $100 \mathrm{a}^{156}$ Thus, from its unexpected origins in the power to remove trade barriers, authority for environmental regulation has grown into a separate, explicit provision of the EC Treaty. This evolution aptly illustrates what seems to be a worldwide trend toward centralized environmental regulation.

\section{International Law}

Compared to the United States or even the E.U., international environmental law is a new and fragile creation. One might even question whether international environmental law deserves to be classified under the heading of multijurisdictional regulation. The basic principle of international law, after all, is that it binds states only with their own consent. ${ }^{157}$ In addition, many of the obligations created by the instruments are vague, and sanctions for noncompliance are few and often ineffectual. Are international environmental treaties actually binding regulations, with some kind of coercive effect on conduct, or are they merely multilateral endorsements of pious platitudes, lacking any bite?

Despite the temptation to dismiss international environmental law as the jurisprudential equivalent of vaporware, there are reasons to take seriously the possibility of an emerging regulatory regime. Specifically, the compliance problem may not be as severe as it seems. In a recent book, Abram and Atonia Chayes make a persuasive argument that international agreements do play a significant role in molding state conduct. ${ }^{1.58}$ They contend that formal enforcement is of limited efficacy, whereas various informal types of pressure to conform with international norms may have more influence:

\footnotetext{
${ }^{156}$ Stewart, supra note 55, at 49 n.15. A new procedure is established in Article 130s(1). Article $130 \mathrm{r}(2)$ provides that "Community policy on the environment shall aim at a high level of protection taking into account the diversity of situations in the various regions of the community." EC Treaty, supra note 47, art. 130r. One commentator has suggested that this increase in legislative power occurred because the German government needed such a side-deal in order to make the move toward a unified European currency politically acceptable. Michael J. Baun, The Maastricht Treaty as High Politics: Germany, France, and European Integration, 110 Pol. Sci. Q. 605, 619 (1995-96).

${ }^{157}$ Developments in the Law: International Environmental Law, 104 Harv. L. Rev. 1484, 1587 (1991) [hereinafter "Developments"].

${ }^{15 x}$ Abram Chayes \& Antonia Handler Chayes, The New Sovereignty: Compliance with International Regulatory Agreements (1995).
} 
That the contemporary international system is interdependent and increasingly so is not news. Our argument goes further. It is that, for all but a few self-isolated nations, sovereignty no longer consists in the freedom of states to act independently, in their perceived self-interest, but in membership in reasonably good standing in the regimes that make up the substance of international life. To be a player, the state must subinit to the pressures that international regulations impose. ... The need to be an accepted inember in this complex web of international arrangements is itself the critical factor in ensuring acceptable compliance with regulatory agreements. ${ }^{159}$

Moreover, economic integration, through free trade agreements such as GATT, increases the density of international interaction and thus may indirectly increase the incentive to comply even with unrelated environmental agreements. ${ }^{160}$

The Chayeses' analysis of the compliance issue may be considered optimistic, but the difference between environmental federalism at the international level and the domestic variety is only one of degree. Indeed, even within a well-integrated system such as the United States, local compliance is not an automatic reflex and coercion can be an unreliable instrument. As commentators have observed, both Congress and the Environmental Protection Agency have found it necessary on important occasions to negotiate with state governments in order to obtain their cooperation. ${ }^{161}$ While international environmental law is

${ }^{159}$ Id. at 27. As they explain:

The largest and most powerful states can sometimes get their way through sheer exertion of will, but even they cannot achieve their principal purposes-security, economic well-being, and a decent level of amenity for their citizens-without the help and cooperation of many other participants in the system, including entities that are not states at all. Smaller and poorer states are almost entirely dependent on the international economic and political system for nearly everything they need to maintain themselves as functioning societies.

Id. See also Christopher D. Stone, The Gnat is Older than Man: Global Environment and Human Agenda 101 (1993) (stating that the "compliance problem is serious," but "foundations of the world order are not as flimsy as they are often depicted").

${ }^{160}$ For a theoretical discussion of the linkage issue, see Grant Hauer \& Ford C. Runge, International Dispersion of Pollution Externalities 23-25 (Dec. 17, 1996) (unpublished manuscript, on file with the Virginia Law Review Association).

${ }^{16 t}$ See John P. Dwyer, The Practice of Federalism Under the Clean Air Act, $54 \mathrm{Md}$. L. Rev. 1183, 1199-1219 (1995); Arnold Reitze, Federalism and the Inspection and Maintenance Program Under the Clean Air Act, 27 Pac. L.J. 1461, 1513-14 (1996). Implementation has also been a major issue within the E.U. See Jared Blumenfeld, 1994: The Year That Regional Environmental Enforcement Gets Tough? An Analysis of NAFTA Envi- 
still far softer than domestic law, it is not merely an idealistic fantasy to consider it a form of law rather than merely an exercise in public relations.

Environmental issues have increasingly moved to the forefront of international relations. Although the international regime is nowhere near as well developed as either the United States or the E.U., there are an increasing number of international agreements on environmental matters such as endangered species, marine pollution, the greenhouse effect, and whales, amounting to hundreds if not thousands of pages of text. ${ }^{162}$ There is some reason to think that we may be in the early stages of the development of a genuine regime of international environmental protection.

If such a regime does emerge, its shape may be presaged by the Montreal agreement to preserve the ozone layer, ${ }^{163}$ which is by all accounts the most notable success story to date in international environmental law. ${ }^{164}$ The ozone layer presents the classic commons problem. Its benefits, in the form of protection from ultraviolet radiation, are a pure public good, from whom no one can be excluded, but significant economic incentives exist for individual nations to produce ozone-destructive chemicals such as CFCs. These economic incentives are heightened by free trade, which makes it possible for an errant nation not only to produce CFCs for its own use but to expand into the global market. The successful negotiation of this agreement is an auspicious omen for even more serious global problems such as the greenhouse effect.

The Montreal Protocol has three notable characteristics that may help explain its ability to overcome the free rider problem. First, rather than attempting to negotiate a permanent regula-

ronmental Side Agreement and Maastricht Treaty, 16 Int'l Env't Rep. (BNA) 959 (Dec. $15,1993)$.

${ }^{162}$ See Lakshman D. Guruswamy, Geoffrey W.R. Palmer \& Burns H. Weston, Supplement of Basic Documents to International Environmental Law and World Order 103-1124 (1994) (excerpts of environmental treaties). The next major challenge is global warming, and the initial treaty framework for dealing with it is already in place. See Laura $\mathrm{H}$. Kosloff \& Mark C. Trexler, Global Warming, Climate-Change Mitigation, and the Birth of a Regulatory Regime, [1997] 27 Envtl. L. Rep. (Envtl. L. Inst.) 10,012 (Jan. 1997).

${ }_{163}$ Montreal Protocol on Substances that Deplete the Ozone Layer, Sept. 16, 1987, 26 I.L.M. 1541 (1987) [hereinafter Montreal Protocol].

${ }^{164}$ Developments, supra note 157, at 1543 n.116 (Montreal Protocol as landmark international agreement). 
tory regime, proponents viewed ozone protection as a continuing process, beginning with the earlier Vienna Convention, which was fairly aspirational, and leading through Montreal to the later London agreement to roll back CFC production and ban some uses entirely. Second, some sanctions (notably in the trade area) were created to deal with free riders, primarily by blocking them from selling CFCs and CFC-produced products. ${ }^{165}$ Third, economic incentives were provided to assist developing countries in compliance; the current plan calls for a $\$ 240$ million international ozone fund. Of course, the ozone agreement may in the end prove unsuccessful, or it may remain an isolated episode, but it does seem a favorable indication of the prospects for international environmental regulation..$^{166}$

Interestingly enough, free trade helped make the ozone convention possible by providing an incentive for companies to promote uniform regulations on the subject. By the mid-1970s, legislation against CFCs was being actively promoted at the state level in the United States, leading industry to favor uniform federal regulation. ${ }^{167}$ Even before federal regulation came into play, U.S. consumers had already turned against CFCs, dropping consumption of spray cans by almost two-thirds. ${ }^{163}$ Given the demise of much of the domestic market for CFCs, industry had an interest in securing the broadest possible international market for possible substitutes. ${ }^{169}$ Indeed, U.S. industry ultimately supported the government's strongly environmentalist position in the international negotiations. ${ }^{70}$ When Congress passed unexpectedly strong controls on methyl chloroform, U.S. industry discovered that a weak U.S. negotiating position on the

${ }^{165}$ Montreal Protocol, supra note 163 , at art. 4. As these sanctions illustrate, free trade and environmental regulation obviously do collide on some occasions. These collisions receive more attention but may ultimately be less significant than the ways in which the two are mutually supportive.

${ }^{165}$ For a brief discussion of the convention's success, arguing that it may not be easily replicated, see Stone, supra note 159, at 81-83.

${ }^{1}{ }^{k 7}$ See Richard Elliot Benedick, Ozone Diplomacy: New Directions in Safeguarding the Planet 31 (1991).

${ }^{16 \times}$ See id. at 27-28.

${ }^{169}$ See id. at 165 . See also id. at 111-12 (discussing DuPont's decision to halt production of CFCs and halons, accelerate research into substitutes, and support an international phaseout).

inu Id. at 47. 
subject created the possibility that its competitors would face less stringent controls. ${ }^{171}$ The United States then reevaluated its position, ultimately resulting in a phaseout agreement. ${ }^{172}$ If CFCs had been produced and sold on a purely local basis, industry would have lacked any incentive to support uniform regulation. It was the globalization of the economy, made possible by free-trade rules, that provided this incentive.

\section{CONCLUSION}

In one not unappealing vision of federalism, the national government ensures free trade but does not regulate environmental matters; the state governments do regulate but are constrained to reach efficient results by an interjurisdictional race to optimality. ${ }^{173}$ The national government thus is a vigilant guardian of free trade but a nonparticipant in regulation.

This combination of federal roles, however, seems unsustainable. As we have seen, despite the political antagonisms between their advocates, free trade and environmental regulation are closely intertwined. Historically, free-trade regimes and regulatory regimes have grown up hand in glove in both the United States and the E.U.; there are some early if highly uncertain signs that the same developments may occur internationally. As a matter of theory, neither type of legal regime is necessary if perfect competition exists between jurisdictions. The same kinds of imperfections which suggest the need for legally protecting free trade, however, also tend to support efforts to harmonize or coordinate environmental regulations.

Perhaps this parallelism should come as no surprise. Both free trade agreements and environmental regulations are ways in which a collectivity can override the preferences of a local governing body-the only difference is that in one situation the local body prefers too high a level of regulation, causing a trade barrier, whereas in the other, it prefers too low a level, causing

${ }^{171}$ Id. at $173-74$.

172 Id. at 174.

${ }^{173}$ See Barry R. Weingast, The Economic Role of Political Institutions: MarketPreserving Federalism and Economic Development, 11 J.L. Econ. \& Org. 1 (1995). For a critique of Weingast, see Jonathan Rodden and Susan Rose-Ackerman, Does Federalism Preserve Markets?, 83 Va. L. Rev. 1521 (1997). 
environmental damage. The political problems in both cases are quite similar: Environmental regulation imposes costs on producers to benefit a diffuse group, while trade law does precisely the same thing by depriving those producers of protectionist benefits. In short, the environmental and trade regimes are mirror images. The sharp political conflicts between their supporters mask a deep underlying structural unity.

In both regimes, the fundamental question is whether to pursue a laissez faire policy, letting the invisible hand guide each jurisdiction to an optimal policy. Justified or not, the general trend seems to be a turn away from laissez faire toward the shelter of overarching multilateral regulation, both as to trade and environment.

Assuming these various multilateral legal regimes are basically justified, we face very difficult issues of institutional design. Experience under the U.S. dormant Commerce Clause, Article 30 of the EC Treaty, and GATT all indicate the considerable difficulties of distinguishing legitimate environmental regulations from gratuitous trade barriers, except in cases of clearcut discrimination. The U.S. experience also demonstrates the difficulties of constructing an appropriate form of multijurisdictional environmental regulation without losing the virtues of decentralization. These tasks will be difficult enough in any event. They are apt to be practically impossible so long as we view the relationship between the two regimes as fundamentally antagonistic rather than largely symbiotic. 
